\title{
РІЗНОВИДИ МАНІПУЛЯЦІЙ ФОТОКОНТЕНТОМ МЕДІА У КОНТЕКСТІ ІНФОРМАЦІЙНО-СМИСЛОВОЇ ВІЙНИ
}

\author{
Костянтин Родигін* \\ Інна Срмакова \\ Донецький національний університет імені Василя Стуса, \\ вул. 600-річчя, 21, 21021, Вінниця, Україна \\ e-mail: k.rodygin@donnu.edu.ua \\ i.iermakova@donnu.edu.ua \\ *https://orcid.org/0000-0002-2948-5393
}

Стаття має на меті систематизувати основні різновиди використання візуального (фотографічного) контенту медіа як об'єкта та інструмента маніпуляцій у контексті інформаційно-смислової війни. Попри реноме документальності, що супроводжує феномен фотографії від його виникнення, технічні та виражальні засоби надають широкий спектр можливостей для потенційних маніпуляцій.

Наявні способи маніпулювання зображальним контентом медіа можна розділити на чотири принципові напрямки: 1) постановна фотографія (маніпуляції на етапі зйомки); 2) ретуш і монтаж (маніпуляції на етапі постобробки); 3) фотофейки (маніпуляції на етапі контексту); 4) маніпуляції невербальним підтекстом сприйняття за допомогою засобів художньої виразності тощо.

Ключові слова: фотографія; фотожурналістика; інформаційно-смислова війна; фотоманіпуляції; постановна фотографія; ретуш; фотофейк.

Постановка проблеми. В умовах сучасного перенасиченого інформаційного простору важливим джерелом в сприйнятті тієї чи іншої інформації стає саме візуальний контент. Часто інформація, що не має візуальної ілюстрації, залишається без належної уваги. Зображення швидше, легше сприймається, має універсальну мову і не потребує перекладу. Особливо це стосується фотографічних зображень. Відтак фотожурналістика володіє особливою силою впливу на маси, а візуальний і зокрема фотографічний контент стає потенційною зброєю інформаційно-смислових воєн.

3 настанням цифрової епохи технології отримання та обробки фотографій стали доступні кожному, хто має комп'ютер чи електронний гаджет. Для доволі якісної обробки тепер не потрібні абсолютно-спеціальні знання. Розвиток техніки та і1і програмного забезпечення значно спрощує втручання в первинне зображення. У підсумку сьогодні стає зрозумілим, якою нескінченно великою є дистанція, що відокремлює створене зображення від фрагмента світу, який у той момент опинився перед об'єктивом.

(C) Родигін К., Срмакова I., 2020 
Теоретичне підгрунтя дослідження. Буквально з моменту винаходу фотографії як засобу фіксації зображення люди стали розглядати її як щось покликане надати докази того, що світ такий, яким ми його бачимо. Як пише Томас Вілер, віра в істинність фотографії майже настільки стара, наскільки й сама фотографія, згідно зі своїми хімічними і механічними властивостями, які, здавалося б, надають притаманної їй об'єктивності ${ }^{1}$. Унікальний спосіб фіксування дійсності - фотографія лише зображенням, що отримане завдяки прямому фізичному контакту між об'єктом і носієм: це не імітація, як, наприклад, картина, а «відбиток» самого фізичного об'єкта, реалізований через фізичний же процес. Саме цей фізичний процес і зумовив той факт, що фотографія більшою мірою, ніж інші способи візуального вираження, підтверджує статус носія істини. Як наслідок, читач не встигає обдумати, проаналізувати матеріал, і споживає інформацію в тому вигляді, в якому отримує. Документальна природа фотографії переконує його в тому, що зображення є таким, якою була дійсність. Вона викликає довіру у читача, тому не дивно, що саме цю властивість фотографії неодноразово використовували для управління суспільною свідомістю. Сьюзен Зонтаг зауважувала: «Фотографія надає свідоцтва. Про щось ми чули, однак, сумніваємося - але якщо нам покажуть фотографію, це буде підтвердженням»².

Нині, в епоху масового поширення цифрових маніпуляцій із фотоконтентом, кількість прихильників тези, що фотографія показує нам реальність такою, якою вона $\epsilon$, меншає. Однак цю проблему обговорюють ще принаймні 3 початку ХХ ст. Варто навести у хронологічному порядку слова таких майстрів фотографії, як репортер Льюїс Хайн: «Фотографія не бреше, але брехуни вміють фотографувати» (1909); пейзажист Ансель Адамс: «Реальність - лише один із елементів процесу створення фотографії» (1959); портретист Річард Аведон: «Усі фотографії точні, але жодна не $\epsilon$ істиною» (1985).

Американський теоретик медіа Вільям Мітчелл писав: «складається враження, що виникла загроза цілісності оригінальної фотографії, суб'єкта та об'єкта фотографії, самого часу і місця». Тривога, яку спричинюють цифрові зображення, - результат розмивання межі між об'єктивним і суб'єктивним, причиною і наслідком Специфічною особливістю цифрової фотографії є відсутність відмінностей між оригінальним зображенням, зробленим за допомогою фотокамери, i його копією. Також специфіка створення цифрової фотографії зумовлює відсутність фізичного доказу існування відображеної події, на відміну від плівкового негатива в аналоговій технології. У такій ситуації постає питання правомірності цифрової фотографічної репрезентації, помножене на постмодерністські сумніви щодо реальності фотографії як такої5. Розвінчання або ослаблення віри в правдивість фотографій може підривати довіру до зображальної журналістики в усіх її формах.

\footnotetext{
Wheeler, Thomas H. (2002), Phototruth Or Photofiction?: Ethics and Media Imagery in the Digital Age, Routledge, Oxford, p. 10-11.

2 Сонтаг, С. (2013), O фотографии, Ад Маргинем Пресс, Москва, с. 15.

3 Mitchell, W.J. (1992), The Reconfigured Eye, Cambridge, MA, p. 8.

4 Ibid., p. 12.

5 Ганюшин, А. А. (2014), «Восприятие и манипуляции в цифровой фотографии в 1990-2000 гг.», Медиаскоп: электронный научный журнал, № 1. URL: http://www.mediascope.ru/node/1491 (дата перегляду 01 листопада 2019)
} 
3 іншого боку, великим викликом для зображальної журналістики як частини суспільного життя стала інформаційна війна як інструмент потужної гібридної війни. Протягом останніх 5 років російської агресії проти України спостерігаємо значну трансформацію медіа й зокрема - фотожурналістики. Медіа та соціальні мережі перетворюються на канали відкритої чи завуальованої пропаганди, поширення дезінформації, фейків, мови ворожнечі, маніпуляцій суспільною свідомістю, смислових диверсій. Фотографія стає дієвим інструментом дезінформації, дезорієнтації, фактором спотворення «дійсності» та зброєю тепер вже не лише інформаційної, а й смислової війни. За допомогою візуального контенту відбувається не лише маніпуляція неправдивою інформацією, а й впровадження ворожих символів та смислів. Ставлення до фотозображення як до копії дійсності стає небезпечним.

Відомий фахівець у галузі інформаційної війни Георгій Почепцов зазначає: «це вже не інформаційна, а смислова війна. Достовірність факту тут не є настільки важливим параметром, як у випадку з інформаційним простором. У крайньому разі завжди можна знайти інший факт, якщо цей не підійде. Факт - вторинний, первинним $€$ необхідний образ-смисл» ${ }^{6}$. Оскільки образ у сучасному інформаційному просторі обігнав за ступенем реальності факт, факт виявляється вторинним. Машина інфовійни працює з образом окремо, а $з$ фактом окремо; потрібний образ робить яскравим, а непотрібний факт - каламутним і суперечливим. При цьому найбільш ефективним інструментом у контексті створення таких образів виступає саме зображальна журналістика.

Стаття має на меті узагальнити та систематизувати основні різновиди використання візуального (фотографічного) контенту медіа як об’єкта та інструмента маніпуляцій у контексті інформаційно-смислової війни.

Методологія дослідження спирається на концепцію інформаційно-смислової війни Г. Почепцова, теоретичні розвідки С. Зонтаг з філософії фотографії, базується на системному підході, загальнонаукових методах аналізу, синтезу, порівняння.

Виклад основного матеріалу дослідження. Документальна природа фотографії переконує глядача в тому, що зображення є таким, якою була дійсність. Відповідно, її цінність - в унікальній фіксації моментів подій, які неможливо організувати чи підлаштувати. Вона викликає довіру. Не дивно, що саме цю властивість фотографії неодноразово використовували для управління суспільною свідомістю.

Український воєнний фотожурналіст Олексій Фурман, узагальнюючи різні способи маніпуляції з фотозображенням, поділяє їх на три групи:

1) маніпуляції на етапі зйомки, якщо автор робить постановку;

2) маніпуляції на етапі постобробки, коли можливими є ретуш і монтаж зображення;

3) маніпуляції на етапі контексту, коли світлина отримує заздалегідь хибний підпис або заголовок?.

Іноді маніпуляції можуть відбуватися на двох або на трьох етапах одразу, посилюючи загальний ефект фейкового повідомлення.

6 Почепцов, Г. (2016), Смисли $і$ війни: Украйна $і$ Росія в інформачійній $і$ смислових війнах, Видавничий дім «Києво-Могилянська академія», Київ, с. 5-6.

7 Тимошенко, Д. (2018), «Как фотофейки работают на войне», Paдio Свобода, 05 липня. URL: https://www.radiosvoboda.org/a/donbass-realii/29341812.html (дата перегляду 01 листопада 2019) 
За словами воєнного фотокореспондента Едді Адамса, «Фотографії є найпотужнішою зброєю в світі. Люди вірять їм; але фотографії брешуть, навіть без маніпулювання ними. Вони - лише напівправда» ${ }^{8}$. Інакше кажучи, найчесніше фото може бути нечесним, якщо воно відірване від контексту.

Беручи за основу наведену класифікацію маніпуляцій з фотографічним контентом, вважаємо за доцільне доповнити її, схематично узагальнити (Таблиця 1) та розглянути окремо кожен напрямок класифікації.

Постановний спосіб зйомки історично $є$ найдавнішим у фотографії. Історія фотожурналістики свідчить, що постановки супроводжують новинну фотографію чи не з часів її виникнення. Серед дослідників побутує думка, що абсолютно достовірну документальну фотографію зробити неможливо, бо для цього потрібно виключити з усіх процесів створення фото людину. Зокрема, Михайло Салаєв у статті «Документальне та постановне у фотографії» вказує, що документальна фотографія - це різновид фотожурналістики, де фотограф намагається зробити об’єктивний та безпристрасний кадр, який правдиво передає те, що відбувалось. Сюди дослідник відносить стріт-фотографію, фото воєнних подій та фоторепортажі. «Документальне - мистецтво факту, а художнє - мистецтво вигадки»9.

Відтак, коли з якихось причин неможливо було зробити світлину - «дзеркало дійсності», або треба було навмисно з певних причин чи обставин зробити імітацію дійсності, фотографи вдавалися і вдаються до постановки «подій», тобто фальсифікації. Такі постановні кадри порушують документальну природу репортажних фото, їх не можна видавати за документальні, і вони мають бути відповідно марковані.

Розглянемо кілька прикладів фотографічних постановок та їхнє значення в історії фотожурналістики. На відомому знімку піонера воєнної фотожурналістики Роджера Фентона «Долина смертної тіні» (Кримська війна, 1855 р.) зображене поле бою $з$ розкиданими гарматними ядрами. Вони беззаперечно драматизують сцену, впливаючи на сприйняття. Але на іншому знімку можна спостерігати ті самі ядра, що лежать складені в канаві. Думки щодо того, яка світлина була знята першою, різняться. Кінорежисер Еррол Морріс написав серію нарисів, досліджуючи докази, та зробив висновок, що фотографію без ядер зробили першою, але невідомо, хто переносив ядра на дорогу для другого фото - чи їх навмисне розмістив на дорозі сам Фентон для посилення картини, чи солдати - у процесі пересування для повторного використання? ${ }^{10}$

У сучасних умовах російської гібридної війни проти України та застосування технологій інформаційних маніпуляцій проблема постановних фото знову привертає увагу дослідників медіа. Пропагандистська машина за потреби вдається і до постановки, аби сфальсифікувати дійсність і надати «візуальний доказ» фактам, яких немає, але вони потрібні для ефективної інформаційної війни. Приклад такої

\footnotetext{
8 Сияк, И. (2016), «Казнить нельзя помиловать: Как создаются и наказываются постановочные фотографии войны», Bird in Flight, 27 августа. URL: https://birdinflight.com/ru/professiya/20160826znamenitye-photo-postanovki.html (дата перегляду 01 листопада 2019)

9 Салаев, М. (2013), «Документальное и постановочное в фотографии», Media-shoot.ru. URL: http://media-shoot.ru/publ/30-1-0-301 (дата перегляду 01 листопада 2019)

${ }^{10}$ Dicker, R. (2012), “Valley Of The Shadow Of Death,' Famous Early War Photo, A Staged Fake, Investigator Says", Huffington Post, January 10. URL: https://www.huffpost.com/entry/valley-of-theshadow-of-death-fake n 1928760 (accessed 01 November 2019)
} 
маніпуляції, зокрема, з використанням образів дітей з метою емоційного впливу на глядача, розглянув український блогер Денис Казанський у матеріалі «Как делается пропаганда» ${ }^{11}$.

На жаль, не лише російські медіа вдаються до маніпулювання правдивістю фото. Окремим предметом вивчення став аналіз використання фотозображень у висвітленні війни на сході України на прикладі публікації постановних фотоматеріалів Дмитра Муравського під назвою «Перемир'я в Широкиному» як найбільш резонансного факту порушення основних засад журналістики в сучасному інформаційному просторі.

На час публікації матеріалів автор обіймав посаду керівника Координаційно-інформаційного центру при Управлінні комунікації і преси Міноборони та радника міністра оборони. Світлину з іронічною назвою «Перемир'я в Широкиному», на якій зображені двоє українських солдатів, що несуть на собі пораненого побратима на тлі вибуху снаряда або міни, називали у мережі «зразковим» прикладом фронтової фотожурналістики, а також доказом порушення перемир'я з боку незаконних збройних угрупувань на Донбасі. Водночас професійні фотографи та військові експерти засумнівалися щодо правдивості фото, вважаючи його постановним, а вибух - влаштований спеціально за допомогою піротехніки ${ }^{12}$.

Після резонансних суперечок та викриття автор фото зізнався в тому, що фото було підготовлене і постановка таки була. Але цей випадок вже встиг зашкодити репутації української журналістики та послужити інформаційною зброєю проти України в руках Росії, що звинуватила українську сторону в імітації бойових дій проти самих себе. Зрештою Муравський був звільнений із посади радника Міністра оборони. За словами Степана Полторака, «ми не маємо права допустити сумнівів серед світової спільноти щодо справжності бойових дій на сході України» ${ }^{13}$.

Дискусія на тему, хто має рацію - фотографи чи Муравський - викрила ще одну суспільну проблему: відсутність запиту на доступ до правдивої інформації, нерозуміння основних стандартів журналістики, позаяк правдивість, відсутність постановки і заборона ретуші є основоположними принципами документальної фотографії.

Іншим поширеним способом маніпуляції з фотографіями (Таблиця 1) є втручання в зображення на етапі обробки, ретушування або монтажу.

Поширеною $є$ думка, що доступні технології заохочують і провокують нові шляхи й способи редагування фотографій. Але понад століття тому було інакше: саме обмеженість ресурсів обробки призводила до маніпуляцій в медіа. Спочатку більшість публікованих зображень це були гравюри, і для художників звичною була свобода їх виконання в найбільш естетично приємному та ефектному вигляді. Попри документальну природу фотографії, втручання у зміст фотографічного зображення були не лише технічно можливими, а й широко практикованими задовго до цифро-

${ }^{11}$ Казанский, Д. (2016), «Как делается пропаганда», Блог Дениса Казанского, 05 декабря. URL: http://deniskazansky.com.ua/kak_delajetsa_propaganda/ (дата перегляду 01 листопада 2019)

12 Савченко, Г. (2016), «Украинские фотографы усомнились в правдивости снимков Дмитрия Муравского», Bird in Flight, 22 августа. URL: https://birdinflight.com/ru/novosti/ industriya/20160822-muravskiy.html (дата перегляду 01 листопада 2019)

13 Online.ua (2016), «Відставка через скандальне фото війни: Полторак зробив гучну заяву», 28 серпня. URL: https://novyny.online.ua/751488/vidstavka-cherez-skandalne-foto-viyni-poltorakzrobiv-guchnu-zayavu/ (дата перегляду 01 листопада 2019) 
вої ери. Хрестоматійним прикладом може бути створений у 1860-х рр. фотопортрет президента США Авраама Лінкольна: насправді на фото лише голова Лінкольна, а решту зображення взято зі знятого ще у 1840-х рр. портрета віце-президента Джона Келхуна, який походив 3 південних штатів і мав докорінно інші політичні погляди як прихильник рабовласництва ${ }^{14}$.

Так само хрестоматійними є історичні приклади, коли з фотографій за допомогою ретуші видаляли «небажаних» осіб. Ця практика була поширена в урядах багатьох країн, проте найтиповішою вона була для СРСР сталінської доби. Девід Кінг присвятив цьому явищу книгу з промовистою назвою «Зниклі комісари» ${ }^{15}$.

Фотоманіпуляції можуть використовуватися і як засіб «чорного піару» та компрометації політичних опонентів. Наприклад, у 1950 р., у період загострення холодної війни між СРСР і США, американський сенатор Міллард Тайдінгс заперечив твердження сенатора Джозефа Маккарті, що нібито в Державному департаменті США працювали сотні комуністів. У відповідь співробітники Маккарті виготовили композитну фотографію, на якій Тайдінгс веде розмову з Ерлом Браудером, колишнім головою Комуністичної партії США. Насправді на той момент ці політики жодного разу не зустрічались особисто. Поширення цієї фотографії стало однією 3 причин поразки Тайдінгса на чергових виборах ${ }^{16}$.

Яскраві приклади політично мотивованого маніпулювання фотографією з'являються і нині, в умовах цифрової епохи, що значно полегшила застосування таких технік. Зокрема, у 2008 р. в Ірані медіапідрозділ Корпусу вартових ісламської революції «Сепах» опублікував серію знімків запуску іранських ракет, які зазнали значної комп’ютерної редактури. Після того, як одна з чотирьох ракет під час запуску не злетіла, вона була вирізана з оригінального знімка і продубльована сусідньою, щоб у глядачів складалося враження абсолютного успіху тестових стрільб і не виникало сумнівів щодо військової потуги держави ${ }^{17}$.

Інший випадок маніпуляції з фотографією стався у 2000 р. в США, коли Університет Вісконсіна-Медісона (The University of Wisconsin-Madison) розіслав потенційним абітурієнтам брошуру, на обкладинці якої була фотографія студентів університету - уболівальників під час футбольного матчу 1993 р. Співробітниця університетської студентської газети «Daily Cardinal» Анна Гулд звернула увагу на те, що освітлення на фото неоднорідне: обличчя темношкірого студента в лівій частині фотографії освітлене яскравим сонцем, тоді як всі інші учасники сцени перебувають в розсіяній тіні. Згодом з'ясувалось, що зображення темношкірого студента було взято з іншої фотографії і прилаштоване до натовпу вболівальників, щоб підкреслити расову різноманітність студентства університету, оскільки в оригінальному кадрі 3

\footnotetext{
${ }^{14}$ Ворошилова, С. (2017), «Почему знаменитый портрет Линкольна только на $1 / 8$ состоит из Линкольна», Bird in Flight, 26 июня. URL: https://birdinflight.com/ru/mir/20170626-lincoln-fake. $\mathrm{html}$ (дата перегляду 01 листопада 2019)

${ }^{15}$ King, D. (1997), The commissar vanishes: the falsification of photographs and art in Stalin's Russia, Metropolitan Books, New York, 192 p.

${ }^{16}$ The Museum of Hoaxes, "The Tydings Affair". URL: http://hoaxes.org/photo database/image/the tydings affair (accessed 01 November 2019)

${ }^{17}$ Ганюшин, А.А. (2014), «Восприятие и манипуляции в цифровой фотографии в 1990-2000 гг.», Медиаскоп: электронный научный журнал, № 1. URL: http://www.mediascope.ru/node/1491 (дата перегляду 01 листопада 2019)
} 
матчу всі студенти були білими. Згодом керівництво університету спробувало відкликати наклад брошур ${ }^{18}$.

У фотожурналістиці відомі випадки, коли навіть відомі фотографи зловживали довірою читачів та фальсифікували важливі моменти історії. Агенції поширювали фотоматеріали, не здогадуючись про застосовані маніпуляції. Зокрема, гучний резонанс отримав епізод з лауреатом міжнародної професійної премії, американським фоторепортером Браяном Вальскі, якого газета «Los Angeles Times» відрядила в Ірак для висвітлення перебігу воєнної операції у 2003 р. На фото, яке зробив Вальскі, британський солдат на околиці Басри заспокоює схвильованих іракських біженців. Щоб підсилити драматизм історії, автор вирішив змонтувати два знімки, зроблені з різницею у кілька секунд, які були доволі інформативними і сильними для публікації. Саме це змонтоване фото вийшло в «Los Angeles Times» 31 березня 2003 p.; навіть більше, - його використали інші видання. Невдовзі монтаж було викрито. Це шокувало редакторів та журналістів, а Вальскі був звільнений 3 «Los Angeles Times». «Те, що зробив Вальскі, абсолютно неприпустимо, він потоптав довіру до нас наших читачів, - заявив редактор Колін Кроуфорд. - Якщо читачі не зможуть покладатися на нашу чесність, то я не знаю, що у нас взагалі залишиться $\rangle^{19}$.

Окрім маніпуляцій з фотозображенням на етапі зйомки, коли автор здійснює постановку кадра, або на етапі постобробки, коли можна ретушувати зображення, поширеними $є$ і маніпуляції на етапі контексту (Таблиця 1), коли світлина отримує заздалегідь хибний підпис або заголовок ${ }^{20}$.

Під фотофейками ми розуміємо саме такі випадки, в яких здебільшого наголошують не на втручанні у зміст світлини, а на її специфічній інтерпретації в комплексі «зображення-текст» - свідомій зміні чи підміні контексту тієї чи іншої фотографії, внаслідок чого правдивий та об’єктивний знімок стає частиною неправдивого повідомлення.

Використання фотофейків як елементів пропаганди та інформаційної війни має давню історію. Зокрема, ще у 1913 р. у нью-йоркській газеті «American», що належала медіамагнату Вільяму Рендольфу Герсту, з'явилося фото групи дітей, що стояли в океані, піднявши руки над головою, - а подали його як нібито свідчення воєнних злочинів у Мексиці. У підписі стверджувалось: «Як доказ ... варварства ... у Мексиці, Рассел Гастінгс Мілвард, англійський мандрівник, член Королівського географічного товариства Лондона, створив фотографію, показану тут. Батьків цих дітей, як стверджує п. Міллард, вбили федеральні солдати. Дітей загнали у воду, змусили тримати руки над головою, і застрелили пострілом у спину». Картинка не змінилася, але підпис до неї був неправдивим. Мілвард висловив протест, заявивши, що насправді діти на знімку просто весело бавилися і що він попросив їх підняли

${ }^{18}$ The Museum of Hoaxes, "Cut-and-Paste Diversity". URL: http://hoaxes.org/photo database/image/ cut and paste diversity (accessed 01 November 2019)

19 Irby, K. (2003), "L. A. Times Photographer Fired Over Altered Image", Poynter Online. Poynter Center for the Study of Ethics and American Institutions, April 2. URL: https://www.poynter.org/reportingediting/2003/l-a-times-photographer-fired-over-altered-image/ (accessed 01 November 2019)

${ }^{20}$ Тимошенко, Д. (2018), «Как фотофейки работают на войне», Padio Свобода, 05 липня. URL: https://www.radiosvoboda.org/a/donbass-realii/29341812.html (дата перегляду 01 листопада 2019) 
руки, аби зробити картинку кращою. Ба більше, фото було зроблено в британському Гондурасі, а не в Мексиці ${ }^{21}$.

Зауважимо, що апеляція до образу дітей була та є дієвим прийомом пропаганди й емоційної маніпуляції в інформаційно-смислових війнах, оскільки має потужний та універсальний вплив на свідомість, шокує та легко увиразнюється в усталених мемах, що тиражуються без критичного осмислення.

Дуже активно цей образ використовувався в інформаційно-смислових атаках проти України у 2014 р., на початковому етапі російсько-української війни. У соціальних мережах активно ширилися такі фотофейки, зокрема 3 характерним хештегом \#savedonbasspeople. На одній із таких світлин зображена дівчинка, що плаче, сидячи на землі, поряд з тілом літньої жінки. Знімок подавався як ілюстрація «звірств української армії», а дитина - як «жертва бомбардувань». Журналісти знайшли оригінал знімка - кадр із художнього фільму 2010 р. «Брестська фортеця», який російські пропагандисти видали за фото, нібито зроблене на Сході України ${ }^{22}$. Тож маємо водночас приклад іншого поширеного в той час прийому створення фотофейків використання кадрів з художніх стрічок про Другу світову війну або фото зі знімальних майданчиків цих фільмів як нібито документальних фотографій сучасних бойових дій на Донбасі, де українська сторона асоціюється з «фашистами».

Основою іншого типу фотофейків була хибна атрибуція світлин за географічним та хронологічним принципом. Зокрема, неодноразово фото з «гарячих точок»зазвичай Чечні або Близького Сходу - представлялися як фотографії з Донбасу. Стосовно світлин з Чеченських війн це пояснюється деякою схожістю пейзажів, військової форми та техніки ${ }^{23}$. У випадку з Близьким Сходом такої схожості немає, але фейки, хоч їх і можна викрити, все одно мають вплив через некритичне сприйняття інформації аудиторією, що в емоційній напрузі не зауважує деталей.

Для перевірки фотографії часом вистачає ввести посилання на фото в сервіс Google Images, який покаже інші версії цього зображення або подібні до нього. Також маніпуляцію можна впізнати за підписом до фотографії, в якому є ознаки мови ворожнечі та яскраве емоційне навантаження ${ }^{24}$.

Стосовно фейків, цифрових маніпуляцій, постановних світлин існує визначеність щодо неприпустимості використання їх у документальній фотографії, а розвиток медіаосвіти та навичок критичного мислення сприяє розпізнанню та виявленню неякісного або маніпулятивного інформаційно-візуального продукту. Використання ж засобів художньої виразності у візуальному контенті для формування певних невербальних підтекстів $\epsilon$ найбільш тонким інструментом маніпуляцій, який ми вважаємо доцільним виділити в окремий напрямок класифікації (Таблиця 1).

Такий напрямок має свою специфіку. Це не фейки: світлини відповідають події, часу та місцю. На цих фотографіях немає факту втручання графічних редакторів $\mathrm{i}$

\footnotetext{
${ }^{21}$ The Museum of Hoaxes, "Ocean Execution". URL: http://hoaxes.org/photo_database/image/ocean execution (accessed 01 November 2019)

22 StopFake.org (2014), «Кадр из кинофильма «Брестская крепость» представляется как фото с Донбасса». 30 мая. URL: https://www.stopfake.org/kadr-iz-kinofilma-brestskaya-krepostpredstavlyaetsya-kak-foto-s-donbassa/ (дата перегляду 01 листопада 2019)

23 Тимошенко, Д. (2018), «Как фотофейки работают на войне», Рaдіо Свобода, 05 липня. URL: https://www.radiosvoboda.org/a/donbass-realii/29341812.html (дата перегляду 01 листопада 2019)

${ }^{24}$ Там само.
} 
постобробки. Вони не постановні. Можна стверджувати, що їм притаманний документалізм. Але ця категорія фотоконтенту, безперечно, стає ефективним інструментом маніпуляцій та впливу на громадську думку, свідомість та поведінку аудиторії, на сприйняття певного образу - це фотографії, в яких застосовані засоби художньої виразності, як композиція, ракурс, світлотінь, колір та інші, з метою не стільки зафіксувати дійсність, скільки створити певний образ цієї дійсності. Йдеться про знакову систему, в якій знак $€$ не умовним, як у випадку з мовою, а цілком змістовним, наочним фактом зображення.

Наведемо приклад, коли тло зображення змінює «конотацію» зчитування візуального образу. В українському інтернет-виданні «Ракурс» 14 вересня 2018 р. вийшов матеріал під назвою «Документального підтвердження смерті немає: ГПУ продовжить розслідувати злочини терориста Захарченка». Матеріал проілюстровано фотографією Олександра Захарченка, очільника угрупування Донецька Народна Республіка у 2014-2018 pp. На розмитому тлі за спиною Захарченка - зображення білого голуба. Якщо не знати, хто саме зображений на фото, то тло світлини диктує певну символьну аналогію з «білими голубами миру», що не збігається зі смисловим наповненням заголовка та самого матеріалу, де Захарченко фігурує як терорист. Глядач звертає увагу на світлину, зчитує певний образ, потім читає «сенсаційний» заголовок, і лише в третю чергу сам матеріал, де йдеться по те, що «генеральна прокуратура продовжить розслідувати злочини колишнього очільника проросійських бойовиків на окупованій частині Донецької області Олександра Захарченка, попри повідомлення про його загибель ... офіційних документів, які підтверджують загибель лідера терористів, немає. А оскільки територія Донецька наразі не підконтрольна українській владі, провести слідчі дії ... на місці інциденту неможливо» ${ }^{25}$. Проте вибір (свідомий чи ненавмисний) саме такої світлини для ілюстрування цього матеріалу сприяє створенню додаткових невербальних підтекстів у комплексі «зображення-текст», працює на рівні створення образів, які, за словами Г. Почепцова, в інформаційно-смисловій війні стають вагомішими за факти. Разом із цим, такий тип маніпуляцій є дуже тонким, його складно формально кваліфікувати як маніпуляцію, оскільки тут немає ні постановки, ні ретуші, ні грубої підміни контексту фотографії.

Створення певного сприйняття образу через «емоційно забарвлений» візуальний контент останнім часом трапляється доволі часто. Такої маніпуляції зазнає часто образ президента США Дональда Трампа, коли як ілюстрації до стилістично нейтрального новинного матеріалу медіа використовують «характерну» фотографію Трампа, що створює комічний ефект ${ }^{26}$.

Іншим ефективним засобом маніпуляції за допомогою засобів художньої виразності є використання обмеженого кута поля зору або кадрування світлин, при якому змінюється їх сприйняття. 3 сучасних українських прикладів відомою $є$ фотографія

${ }_{25}$ Ракурс (2018), «Документального підтвердження смерті немає: ГПУ продовжить розслідувати злочини терориста Захарченка». 14 вересня. URL: https://racurs.ua/ua/n111031-dokumentalnogopidtverdjennya-smerti-nemaie-gpu-prodovjyt-rozsliduvaty-zlochyny-terorysta.html (дата перегляду 01 листопада 2019)

${ }^{26}$ УНIAH (2018), «Трамп створив командування Космічними силами CША», 18 грудня. URL: https://www.unian.ua/world/10382259-tramp-stvoriv-komanduvannya-kosmichnimi-silami-ssha.html (дата перегляду 01 листопада 2019) 
нібито втечі президента України Петра Порошенка від людей на мітингу в Житомирі під час передвиборчої кампанії 2018 р. На сильно кадрованому знімку зафіксований момент, коли Порошенко переступає через калюжу, і складається враження, що він біжить. Насправді ж, як свідчить повна версія фотографії, політик ішов саме до людей, але вони не потрапили в поле кадрованого зображення. Інформацію підтвердив автор фото, кореспондент УНІАН Леонід Шевчук, опублікувавши повну версію цієі сцени. Однак варто зауважити, що кадровану версію також спочатку опублікував i поширив сам автор. Вочевидь, хибна інтерпретація кадрованого фото виникла вже згодом в соціальних мережах, однак можливість такої інтерпретації було закладено саме обмеженням поля фотографії, і автору довелося спростовувати фейк, що виник на основі його світлини ${ }^{27}$.

У редакційному статуті Національної суспільної телерадіокомпанії України, у пункті 2.1.1. «Принцип точності подачі інформації. Перевірка як головний спосіб забезпечення точності» $є$ кілька рядків, які є настановчими щодо вимог до фото- i відеоматеріалів: «Відео-, фото-, аудіоматеріали мають бути автентичними, а застосування монтажу, комп'ютерної обробки чи інших технічних прийомів та художніх засобів виразності з метою акцентування уваги чи посилення образу не повинне вводити громадськість в оману щодо справжності цих матеріалів, обставин чи подій, які вони зображують. ... Архівний матеріал, інсценування (реконструкції), використані для ілюстрування актуальної проблеми або події, мають бути марковані контрастним шрифтом або озвучені ведучим» ${ }^{28}$. Цими вимогами зазначено неприпустимість використання технічних прийомів та художніх засобів виразності задля маніпуляції сприйняттям. На жаль, не всі редакції мають навіть такі мінімально прописані вимоги до фотографічного матеріалу. Звісно, висунути такі вимоги щодо зображення складніше, ніж до тексту. Але ж як саму природу фотографічного зображення, так і суб'єктивність його сприйняття та оцінювання візуальної інформації важко сформулювати у конкретні претензії.

Результати і перспективи подальших досліджень. Запропонована схема класифікації дає змогу систематизувати прояви різного характеру маніпулювання з візуальним контентом медіа в контексті інформаційно-смислової війни. Виділено новий напрямок маніпуляцій - використання засобів художньої виразності та поєднання візуальної й текстової інформації для тонкої маніпуляції підтекстом сукупного повідомлення, закладення в нього додаткових смислових конотацій при формальному дотриманні усталених вимог документальності - відсутності постановки, ретуші або фальсифікації контексту. Такий тип маніпуляцій є складним для виявлення, але не менш дієвим за інші, оскільки, уникаючи прямої атаки на факти, працює на формування образів, які в умовах смислової війни важать більше, ніж факти.

Перспективними напрямками розвитку цього дослідження є: а) поглиблений аналіз кожної групи маніпуляцій в історичному та сучасному вимірі; б) вивчення наявних та розробка нових методик виявлення та протидії означеним різновидам маніпуляцій з візуальним контентом медіа в інформаційно-смисловій війні.

\footnotetext{
${ }^{27}$ InfoResist (2019), «Снимок, на котором Порошенко убегает от толпы, оказался фейком: что произошло на самом деле», 12 марта. URL: https://inforesist.org/snimok-na-kotorom-poroshenko-ubegaet-ottolpy-okazalsya-fejkom-chto-proizoshlo-na-samom-dele/ (дата перегляду 01 листопада 2019)

28 UA: Суспільне мовлення, «Редакційний статут ПАТ «НСТУ»». URL: https:/suspilne.media/ documents/83 (дата перегляду 01 листопада 2019)
} 


\section{Висновки}

Попри реноме документальності, що супроводжує феномен фотографії від самого моменту його виникнення, технічні та виразні засоби надають широкий спектр можливостей для потенційних маніпуляцій. У цифрову епоху розвиток техніки та програмного забезпечення значно спрощує схожі втручання в первинне зображення. Дистанція, що відокремлює створене зображення від фрагмента світу, який у той момент опинився перед об'єктивом, може бути дуже істотною.

Наявні способи маніпулювання зображальним контентом медіа можна розділити на чотири принципові напрямки:

1. Постановна фотографія (маніпуляції на етапі зйомки), в якій потрібний образ конструює сам автор в процесі зйомки і подає його як документальний факт.

2. Ретуш і монтаж (маніпуляції на етапі постобробки), коли за допомогою втручання в зображення цифровими чи аналоговими засобами, порушення цілісності факту і моменту, реальність коригується постфактум.

3. Фотофейки (маніпуляції на етапі контексту), в яких фотографію поміщують у зманіпульований контекст, один факт видається за інший. У такий спосіб навіть правдива фотографія може перетворитися на неправду в хибному контексті.

4. Маніпуляції невербальним підтекстом сприйняття комплексу візуальної та текстової інформації за допомогою використання засобів художньої виразності, ракурсу, композиції тощо для зміни нюансів сприйняття матеріалу. Цей різновид маніпуляцій $є$ найвитонченішим і може формально не суперечити вимогам документальності фотографії, оскільки не містить постановки, ретуші або явної фальсифікації контексту.

Нині фотографія може виступати дієвим інструментом дезінформації, дезорієнтації, фактом спотворення «дійсності» та зброєю тепер уже не лише інформаційної, а й смислової війни. За допомогою візуального контенту відбувається не лише маніпуляція неправдивою інформацією, а й впровадження ворожих символів, емблем та смислів. «Документальність» фотографії, ставлення до фотозображення як до копії дійсності стають небезпечними для медійного простору та суспільної свідомості.

\section{Основні напрямки використання фотоконтенту медіа як об’єкта та інструмента маніпуляцій}

\begin{tabular}{|c|c|}
\hline $\begin{array}{c}\text { ПОСТАНОВКА } \\
\text { Маніпуляції на етапі зйомки }\end{array}$ & $\begin{array}{c}\text { РЕТУШ I МОНТАЖ } \\
\text { Маніпуляції на етапі постобробки }\end{array}$ \\
\hline $\begin{array}{l}\text { Потрібний образ конструює сам автор у } \\
\text { процесі зйомки і подає його як докумен- } \\
\text { тальний факт }\end{array}$ & $\begin{array}{l}\text { Втручання в зображення, порушення } \\
\text { цілісності факту i моменту, реальність } \\
\text { коригується постфактум }\end{array}$ \\
\hline $\begin{array}{l}\text { ФОТОФЕЙКИ } \\
\text { Маніпуляиії на етапі контексту } \\
\text { Фотографію, зазвичай правдиву, поміщу- } \\
\text { ють у зманіпульований контекст, один } \\
\text { факт видається за інший }\end{array}$ & $\begin{array}{l}\text { НЕВЕРБАЛЬНИЙ ПІДТЕКСТ } \\
\text { Маніпуляиії підтекстом сприйняття } \\
\text { Використання засобів художньої виразнос- } \\
\text { ті, ракурсу, композиції тощо для зміни } \\
\text { нюансів сприйняття матеріалу }\end{array}$ \\
\hline
\end{tabular}




\section{СПИСОК ЛІТЕРАТУРИ}

1. The Museum of Hoaxes, "Cut-and-Paste Diversity". URL: http://hoaxes.org/photo database/image/cut and paste diversity (accessed 01 November 2019)

2. Dicker, R. (2012), “'Valley Of The Shadow Of Death,' Famous Early War Photo, A Staged Fake, Investigator Says", Huffington Post, January 10. URL: https://www.huffpost.com/entry/valley-of-the-shadow-of-death-fake n 1928760 (accessed 01 November 2019)

3. Irby, K. (2003), "L. A. Times Photographer Fired Over Altered Image", Poynter Online. Poynter Center for the Study of Ethics and American Institutions, April 2. URL: https://www.poynter.org/reporting-editing/2003/l-a-times-photographer-fired-over-altered-image/ (accessed 01 November 2019)

4. King, D. (1997), The commissar vanishes: the falsification of photographs and art in Stalin's Russia, Metropolitan Books, New York, 192 p.

5. Mitchell, W.J. (1992), The Reconfigured Eye, Cambridge, MA, 283 p.

6. The Museum of Hoaxes, "Ocean Execution". URL: http://hoaxes.org/photo database/ image/ocean execution (accessed 01 November 2019)

7. The Museum of Hoaxes, "The Tydings Affair". URL: http://hoaxes.org/photo database/ image/the tydings affair (accessed 01 November 2019)

8. Wheeler, Thomas $\overline{\mathrm{H}}$. (2002), Phototruth Or Photofiction?: Ethics and Media Imagery in the Digital Age, Routledge, Oxford, $244 \mathrm{p}$.

9. Online.ua (2016), «Відставка через скандальне фото війни: Полторак зробив гучну заяву», 28 серпня. URL: https://novyny.online.ua/751488/vidstavka-cherez-skandalnefoto-viyni-poltorak-zrobiv-guchnu-zayavu/ (дата перегляду 01 листопада 2019)

10. Ворошилова, С. (2017), «Почему знаменитый портрет Линкольна только на $1 / 8$ состоит из Линкольна», Bird in Flight, 26 июня. URL: https://birdinflight.com/ru/ mir/20170626-lincoln-fake.html (дата перегляду 01 листопада 2019)

11. Ганюшин, А.А. (2014), «Восприятие и манипуляции в цифровой фотографии в 1990-2000 гг.», Медиаскоп: электронный научный журнал, № 1. URL: http://www. mediascope.ru/node/1491 (дата перегляду 01 листопада 2019)

12. Ракурс (2018), «Документального підтвердження смерті немає: ГПУ продовжить розслідувати злочини терориста Захарченка». 14 вересня. URL: https:// racurs.ua/ua/n111031-dokumentalnogo-pidtverdjennya-smerti-nemaie-gpu-prodovjytrozsliduvaty-zlochyny-terorysta.html (дата перегляду 01 листопада 2019)

13. StopFake.org (2014), «Кадр из кинофильма «Брестская крепость» представляется как фото с Донбасса». 30 мая. URL: https://www.stopfake.org/kadr-iz-kinofilmabrestskaya-krepost-predstavlyaetsya-kak-foto-s-donbassa/ (дата перегляду 01 листопада 2019)

14. Казанский, Д. (2016), «Как делается пропаганда», Блог Дениса Казанского, 05 декабря. URL: http://deniskazansky.com.ua/kak_delajetsa_propaganda/ (дата перегляду 01 листопада 2019)

15. Почепцов, Г. (2016), Смисли і війни: Украӥна і Росія в інформачійній і смислових війнах, Видавничий дім «Києво-Могилянська академія», Київ, 316 с.

16. UA: Суспільне мовлення, «Редакційний статут ПАТ «HCTУ»». URL: https:// suspilne.media/documents/83 (дата перегляду 01 листопада 2019) 
17. Савченко, Г. (2016), «Украинские фотографы усомнились в правдивости снимков Дмитрия Муравского», Bird in Flight, 22 августа. URL: https://birdinflight.com/ru/ novosti/industriya/20160822-muravskiy.html (дата перегляду 01 листопада 2019)

18. Салаев, М. (2013), «Документальное и постановочное в фотографии», Media-shoot. $r u$. URL: http://media-shoot.ru/publ/30-1-0-301 (дата перегляду 01 листопада 2019)

19. Сияк, И. (2016), «Казнить нельзя помиловать: Как создаются и наказываются постановочные фотографии войны», Bird in Flight, 27 августа. URL: https:// birdinflight.com/ru/professiya/20160826-znamenitye-photo-postanovki.html (дата перегляду 01 листопада 2019)

20. InfoResist (2019), «Снимок, на котором Порошенко убегает от толпы, оказался фейком: что произошло на самом деле», 12 марта. URL: https://inforesist.org/ snimok-na-kotorom-poroshenko-ubegaet-ot-tolpy-okazalsya-fejkom-chto-proizoshlona-samom-dele/ (дата перегляду 01 листопада 2019)

21. Сонтаг, С. (2013), О фотографии, Ад Маргинем Пресс, Москва, 272 с.

22. Тимошенко, Д. (2018), «Как фотофейки работают на войне», Радіо Свобода, 05 липня. URL: https://www.radiosvoboda.org/a/donbass-realii/29341812.html (дата перегляду 01 листопада 2019)

23. УНІАН (2018), «Трамп створив командування Космічними силами США», 18 грудня. URL: https://www.unian.ua/world/10382259-tramp-stvoriv-komanduvannyakosmichnimi-silami-ssha.html (дата перегляду 01 листопада 2019)

\section{REFERENCES}

1. The Museum of Hoaxes, "Cut-and-Paste Diversity". URL: http://hoaxes.org/photo database/image/cut and paste diversity (accessed 01 November 2019)

2. Dicker, R. (2012), "'Valley Of The Shadow Of Death,' Famous Early War Photo, A Staged Fake, Investigator Says", Huffington Post, January 10. URL: https://www.huffpost.com/entry/valley-of-the-shadow-of-death-fake_n_1928760 (accessed 01 November 2019)

3. Irby, K. (2003), "L. A. Times Photographer Fired Over Altered Image", Poynter Online. Poynter Center for the Study of Ethics and American Institutions, April 2. URL: https://www.poynter.org/reporting-editing/2003/l-a-times-photographer-fired-over-altered-image/ (accessed 01 November 2019)

4. King, D. (1997), The commissar vanishes: the falsification of photographs and art in Stalin's Russia, Metropolitan Books, New York, 192 p.

5. Mitchell, W.J. (1992), The Reconfigured Eye, Cambridge, MA, 283 p.

6. The Museum of Hoaxes, "Ocean Execution". URL: http://hoaxes.org/photo database/ image/ocean_execution (accessed 01 November 2019)

7. The Museum of Hoaxes, "The Tydings Affair". URL: http://hoaxes.org/photo database/ image/the tydings affair (accessed 01 November 2019)

8. Wheeler, Thomas H. (2002), Phototruth Or Photofiction?: Ethics and Media Imagery in the Digital Age, Routledge, Oxford, $244 \mathrm{p}$.

9. Online.ua (2016), "Vidstavka cherez skandalne foto viiny: Poltorak zrobyv huchnu zaiavu", August 28. URL: https://novyny.online.ua/751488/vidstavka-cherez-skandalnefoto-viyni-poltorak-zrobiv-guchnu-zayavu/ (accessed 01 November 2019) 
10. Voroshylova, S. (2017), "Pochemu znamenityi portret Linkolna tolko na $1 / 8$ sostoit iz Linkolna", Bird in Flight, June 26. URL: https://birdinflight.com/ru/mir/20170626lincoln-fake.html (accessed 01 November 2019)

11. Ganiushin, A.A. (2014), "Vospriiatie i manipuliatsii v tsyfrovoi fotografii v 1990 2000 gg.", Mediaskop, No. 1. URL: http://www.mediascope.ru/node/1491 (accessed 01 November 2019)

12. Rakurs (2018), "Dokumentalnoho pidtverdzhennia smerti nemaie: HPU prodovzhyt rozsliduvaty zlochyny terorysta Zakharchenka", September 14. URL: https://racurs. ua/ua/n111031-dokumentalnogo-pidtverdjennya-smerti-nemaie-gpu-prodovjytrozsliduvaty-zlochyny-terorysta.html (accessed 01 November 2019)

13. StopFake.org (2014), "Kadr iz kinofilma «Brestskaia krepost» predstavliaietsia kak foto s Donbassa”, May 30. URL: https://www.stopfake.org/kadr-iz-kinofilma-brestskayakrepost-predstavlyaetsya-kak-foto-s-donbassa/ (accessed 01 November 2019)

14. Kazanskii, D. (2016), "Kak delaietsia propaganda", Blog Denisa Kazanskogo, December 05. URL: http://deniskazansky.com.ua/kak delajetsa propaganda/ (accessed 01 November 2019)

15. Pocheptsov, H. (2016), Smysly $i$ viiny: Ukraina i Rosiia v informatsiinii $i$ smyslovykh viinakh, Vydavnychyi dim "Kyievo-Mohylianska akademiia", Kyiv, 316 p.

16. UA: Suspilne movlennia, "Redaktsiinyi statut PAT «NSTU»”. URL: https://suspilne. media/documents/83 (accessed 01 November 2019)

17. Savchenko, G. (2016), "Ukrainskie fotografy usomnilis v pravdivosti snimkov Dmitriia Muravskogo", Bird in Flight, August 22. URL: https://birdinflight.com/ru/novosti/ industriya/20160822-muravskiy.html (accessed 01 November 2019)

18. Salaiev, M. (2013), "Dokumentalnoie i postanovochnoie v fotografii”, Media-shoot.ru. URL: http://media-shoot.ru/publ/30-1-0-301 (accessed 01 November 2019)

19. Siiak, I. (2016), "Kaznit nelzia pomilovat: Kak sozdaiutsia i nakazyvaiutsia postanovochnyie fotografii voiny", Bird in Flight, August 27. URL: https://birdinflight.com/ru/ professiya/20160826-znamenitye-photo-postanovki.html (accessed 01 November 2019)

20. InfoResist (2019), "Snimok, na kotorom Poroshenko ubegaiet ot tolpy, okazalsia feikom: chto proizoshlo na samom dele", March 12. URL: https://inforesist.org/snimok-nakotorom-poroshenko-ubegaet-ot-tolpy-okazalsya-fejkom-chto-proizoshlo-na-samomdele/ (accessed 01 November 2019)

21. Sontag, S. (2013), O fotografii. Ad Marginem Press, Moscow, 272 p.

22. Timoshenko, D. (2018), "Kak fotofeiki rabotaiut na voinie", Radio Svoboda, July 05. URL: https://www.radiosvoboda.org/a/donbass-realii/29341812.html (accessed 01 November 2019)

23. UNIAN (2018), "Tramp stvoryv komanduvannia Kosmichnymy sylamy SShA”, December 18. URL: https:/www.unian.ua/world/10382259-tramp-stvoriv-komanduvannyakosmichnimi-silami-ssha.html (accessed 01 November 2019) 


\title{
THE KINDS OF MEDIA PHOTOCONTENT MANIPULATIONS IN THE CONTEXT OF INFORMATION AND SEMANTIC WARFARE
}

\author{
Kostiantyn Rodyhin \\ Inna Iermakova \\ Vasyl' Stus Donetsk National University \\ 600-richchia str. 21, 21021, Vinnytsia, Ukraine \\ e-mail:k.rodygin@donnu.edu.ua \\ i.iermakova@donnu.edu.ua \\ ${ }^{1}$ https://orcid.org/0000-0002-2948-5393
}

The article deals with photo manipulations as objects and instruments of an information and semantic warfare. The main objective of the study is to generalize and systematize the basic ways of such photo manipulations. The methodology of the study includes the theoretical works by Heorhii Pocheptsov on an information and semantic warfare, and Susan Sontag on the philosophy of photography. The study was done using the systematic approach, general scientific methods of analysis, synthesis and comparison.

Despite the reputation of its documentalism, photography provides a wide range of possibilities for potential manipulations. In the digital era, the development of hardware and software simplifies such interruptions into original image and its context. A distance between the created image and a fragment of the world in front of the lens can be very significant.

Nowadays, photography can be an instrument of misinformation and a weapon of information and semantic warfare. So, an attitude to photographic content as a copy of reality becomes dangerous towards the media space and social consciousness.

As a conclusion, the present ways of manipulating visual media content can be divided into four principled directions:

1. Staged photography (a manipulation in the phase of shooting).

2. Retouch and montage (a manipulation in the phase of post-production).

3. Photo fakes (manipulations in the phase of context).

4. Manipulations on non-verbal implication of the content by artistic expressive means etc. The significance of this kind is doubtless because it is the most subtle kind of manipulations, formally responding the demands of documental photography: no staged photos, no retouch, no obviously fake messages. This one is the most difficult to recognize and counteract.

Key words: photography; photojournalism; information and semantic warfare; photo manipulations; staged photography; retouch; photo fake. 